\title{
The Creation of the First Overseas Pasteur Institute, or the Beginning of Albert Calmette's Pastorian Career
}

\author{
ANNICK GUÉNEL*
}

Three years after the creation of the Pasteur Institute in Paris (1888), Albert Calmette, a French doctor in the Corps de Santé des Colonies, laid the foundations of its first overseas daughter institute in Cochin-China, a distant French colony. In fact, the Australian Pasteur Institute could also lay claim to be considered the first, as Pasteur's own nephew, Adrien Loir, ' began plans for it as early as 1888 . Nevertheless, the continuous presence of the Pasteur Institute in Indochina, which is still felt in the independent countries today, and the similarities between the strategies adopted by the Saigon Laboratory and other overseas centres made Calmette's mission a model for establishing the Institute abroad.

The gateway opened by this enterprise for the study of tropical diseases is of fundamental importance. We must remember that the first "Pastorian mission" to go abroad was sent to Alexandria in 1883 to study cholera; Emile Roux, fellow doctor and friend of Pasteur from his early days and director of the Institute from 1904 until his death in 1933, took part in it. The French commission's failure, in the light of the discovery of the bacillus by Pasteur's German rival, Robert Koch, was one of the reasons that Pastorian research changed direction. ${ }^{2}$ The idea of the universality of "Pastorian science" developed around the study of the virulence of microbes, which produced in particular the rabies vaccine and thereby led to the consecration of the Institute. This notion went hand in hand with the near total belief in the treatment or prevention of infectious diseases, of which the colonies offered a wide range. ${ }^{3}$

It was no accident that Pasteur's first tropical institute was set up in Indochina. European scientists coveted territory in the Far East and Asia in general. The German school had its disciples in Japan, and the English, especially Patrick Manson in China,

*Annick Guénel, CNRS-INSERM Unit 158, Hôpital Necker, 149 rue de Sèyres, 75015 Paris, France.

I should like to address special thanks to Dr Denise Ogilvie, Director of the Archives at the Pasteur Institute in Paris, who kindly allowed me to study the "Fonds Calmette". I am also indebted to Dr Anne Marie Moulin for her insightful criticism and comments on the first draft of this paper, and to Mrs Mary Shaffer for her commitment and intuitive accuracy in the English translation. I am very grateful to the Fondation Mérieux for the grant which allowed me to embark on an investigation of the history of Pasteur Institutes in Indochina.

\footnotetext{
${ }^{1}$ On Loir's missions in Australia, from 1888 to 1893, see Jean Chaussivert, 'L'Institut Pasteur d'Australie', in M Morange (ed.), L'institut Pasteur. Contributions à son histoire, Paris, La Découverte, 1991, pp. 242-52.

2 Anne Marie Moulin, 'Révolutions médicales et révolutions politiques en Egypte', Revue du monde musulman et de la Méditerranée, 1989, 52-53: 112-23, pp. 115-16.

${ }^{3}$ Idem, 'Bacteriological research and medical practice in and out of the Pastorian School', in A La Berge and M Feingold (eds), French medical culture in the nineteenth century, Amsterdam, Rodopi, 1994, pp. $327-49$, on p. 329.
} 
earned a reputation as pioneers in the field of parasitology. France's conquest of all of Indochina, giving the French their turn to occupy territory, was completed around the same time as the Pasteur Institute in Paris was founded. The latter quickly became a school as Roux inaugurated his "Grand Cours" in microbiology there in 1889. Before the creation in 1906 of the "School for the Application of Colonial Medicine" in Marseilles (commonly known as le Pharo), ${ }^{4}$ military doctors in the colonies who wanted to learn more about laboratory practices made up a significant portion of the students attending classes at the Institute. Calmette, who enjoyed special, accelerated training, was the first in his class.

Although the Pasteur Institute was not the equivalent of the subsequent British schools of tropical medicine (Patrick Manson's in London, and Ronald Ross's in Liverpool ${ }^{5}$ ), it gradually carved out a niche for itself in the development of this speciality. Pastorians commonly correlate Calmette's mission to Saigon from 1891 to 1893 with the appearance of colonial laboratories responsible for the first applications of a discipline which did not come into its own until the turn of the century, via Great Britain. ${ }^{6}$

The creation of the Saigon Laboratory marked not only an important step in the broader history of the exportation of "Pastorian science", seen from a purely French point of view, but also reveals the scientific rivalries in Europe at the end of the nineteenth century. This episode can now be better understood thanks to the recent addition of Calmette's personal correspondence from 1890 to 1893 to the archives of the Pasteur Institute in Paris. ${ }^{7}$ Calmette's letters show that he played a greater role in the definition of this project than previous histories have attributed to him. Given his professional background, and the support he enjoyed from various quarters, the direct connection between the development of colonial public health in Indochina, and France's military and political interests was only strengthened. ${ }^{8}$

Calmette's correspondence during his stay in Saigon also provides a clearer picture of the development of the laboratory and the work carried out there (more than we glean from its publications list), and also of the path Calmette himself pursued towards a career in France. Both of these factors are indicative of the relationship between Pastorian science as it was practised in the centre and at the periphery. Indeed, from the moment the decision was made to create the Saigon Laboratory, Calmette decided to link his own career to the fate of the Pasteur Institute.

\footnotetext{
${ }^{4}$ The Pasteur Institute was tied to the Pharo School through its disciples. For example, PaulLouis Simond, a Pastorian who discovered in India the flea's role in transmitting the plague bacillus, was the School's first assistant-director.

5 Michael Worboys, 'Manson, Ross and colonial medical policy: tropical medicine in London and Liverpool, 1899-1914', in R MacLeod and M Lewis (eds), Disease, medicine and empire: perspectives on western medicine and the experience of European expansion, London and New York, Routledge, 1988, pp. 21-37, on pp. 25-8.

${ }^{6}$ Michael Worboys, 'The emergence of tropical
}

medicine: a study in the establishment of a scientific specialty', in G Lemaine, R MacLeod, M Mulkay and $\mathrm{P}$ Weingart (eds), Perspectives on the emergence of scientific disciplines, The Hague, Mouton, 1976, pp. 75-98.

${ }^{7}$ Archives of the Pasteur Institute in Paris (APIP), Fonds Calmette. Most of the documents are letters from Calmette to his family; only the other correspondents will be mentioned.

8 See Roy MacLeod, 'Introduction', in MacLeod and Lewis (eds), op. cit., note 5 above, pp. 1-18, on p. 3. 


\section{The Beginning of Albert Calmette's Pastorian Career}

\section{Project for a Colonial Laboratory: Myth and Reality}

\section{Calmette, Navy Doctor and "Self-Taught" Pastorian}

Well before the creation of the Offices for Medical Assistance in the various French colonies, the true protagonists of French medical action overseas were doctors from the Royal Navy, later re-christened the State Navy, of which the oldest school dates back to 1720. Calmette graduated from the Navy Medical School (École de Santé Navale) in Brest in 1883 and thus belonged to an old tradition that was unsettled at the end of the nineteenth century by the expansion of microbiology and the first discoveries of pathogenic agents and their vectors in the tropics.

One year out of school, Calmette took part in the China campaign with the Navy squadron of Admiral Courbet. This was his first mission, and it was decisive. He not only had his first contact on land with local pathologies such as lymphatic filariasis, liver abscess, elephantiasis, and so forth, but also met Patrick Manson. Calmette was so taken with Manson's most recent work that he was willing to translate the Scottish doctor's writings on the Culex pipiens mosquito as the intermediate host in the biological cycle of Bancroftian filariasis. After a visit to Saigon, Calmette returned to Paris, where he completed his studies and in 1886, not surprisingly, defended a thesis on "filarian lymphangitis".9

Over the course of his subsequent campaigns, Calmette's penchant for the laboratory was confirmed, or, as he wrote a few years later, for "the study of exotic pathologies according to modern methods"-in shortened form, "exotic pathologies of the future". 10 In 1887 in Gabon he discovered sleeping sickness, but not the trypanosome, "since", he wrote, "my lenses allowed only the study of histological sections". Yet one year later he published a study on the trypanosome. ${ }^{11}$ For his third mission he was forced to abandon the idea of going to a tropical climate - he was newly married-and went instead to SaintPierre-et-Miquelon, where he stayed from 1887 to 1890 . Since there were no new human diseases to explore there, he began to study le rouge de morue, or the red pigmentation in cod. He isolated a micrococcus that causes salted cod to turn red during maritime transport. He identified the origin of the micro-organism (which comes from salt), the conditions in which it develops, and even a "cure": a small amount of sodium sulphite prevents it from proliferating.

Calmette considered this research a "self-initiation" into the methods of microbiology. Nonetheless, he was not entirely satisfied with the results. He was not able to show toxicity of the micro-organism, and the consequences of the phenomenon were merely commercial; when cod has changed colour no one will buy it. More importantly, Félix Le Dantec, also a Navy doctor and later a Pastorian, made the same observations on the Island of Groix, and had his study published before that of Calmette. When he published a second article on the subject in 1891, in the Annales de l'Institut Pasteur, Calmette could not contain his resentment:

\footnotetext{
${ }^{9}$ Albert Calmette, 'Etude critique sur l'étiologie et la pathogénie des maladies tropicales attribuées à la filaire du sang humain', medical thesis, Paris, 1885-86.

${ }^{10}$ APIP, Fonds Indochine, Saint-Pierre-etMiquelon, 22 February 1890.
}

\footnotetext{
${ }^{11}$ Albert Calmette, 'Maladie du sommeil et ses rapports avec la pellagre', Archives de médecine navale, 1888, 50: 321-39. See also, Noël Bernard, La vie et l'oeuvre d'Albert Calmette, Paris, Albin Michel, 1961, p. 58.
} 


\section{Annick Guénel}

He plagiarized my work shamelessly, plundered all the notes that I stupidly lent him when I was at the Institute and worked on this subject under M. Roux . . . That animal thought this was all right because he cited me twice in the course of his work! Not that he will get far, because M. Roux too must have been offended. ${ }^{12}$

During his time at Saint-Pierre-et-Miquelon, Calmette did not, however, forget tropical diseases. He was drafting a new treatise on medical geography with Professor Armand Corre, his first teacher at the École de Santé Navale, with whom he kept up an extensive scientific correspondence. Corre had practised in Indochina, where he was one of the first "vaccinators", and had already written a Traité clinique des maladies des pays chauds, published in 1887 , which their joint work was to complete and update. ${ }^{13}$ Yet apart from this book, which benefited from his recent experience overseas, Calmette was nevertheless dissatisfied, and was highly critical of the lack of development of bacteriological research in French colonial medicine: "We are decidedly lagging far behind in our Navy and colonial hospitals! When will we be taught what we need to know if we do not want to appear ignorant, and be given the working instruments that are lacking everywhere?"14

For Calmette, an avid reader of the Annales de l'Institut Pasteur, Roux's Grand Cours in microbiology at the Institute offered a unique and prestigious way to compensate for the lack of training for French doctors in the colonies. His mission to Saint-Pierre-etMiquelon ended at a time that was ripe for this "three [sic] year old project", and for vaster projects. $^{15}$

France's colonial expansion at the end of the nineteenth century required the creation of a new medical corps in the colonies, in addition to the Navy Health Corps. In 1890 the Corps de Santé des Colonies, later to become the Corps de Santé des Troupes Coloniales, was created to occupy and develop colonial health care structures. A decree stipulated that practising Navy doctors could join, ${ }^{16}$ and Calmette chose to do so. This meant he would be away from France for longer periods of time, but he could also anticipate possible research into "exotic pathologies", which would not be the case with a Navy position. Calmette was also aware of other advantages for his career if he made such a change; moreover, with this plan he hoped to be granted a period of leave at home, for study at the Pasteur Institute.

${ }_{12}^{12}$ APIP, Saigon, 5 October 1891.

${ }^{13}$ Armand Corre, Traité clinique des maladies des pays chauds, Paris, Octave Doin, 1887. Corre, who in 1890 was already an old man, withdrew from his participation in the new treatise, 'Traité de géographie médicale et de climatologie générale du globe'. Calmette took the manuscript with him to Saigon, but the book was never published.

14 APIP, Saint-Pierre-et-Miquelon, letter to Corre, 7 April 1890.

15 Noël Bernard, Pastorian and Calmette's biographer, emphasized that Calmette had been one of the "first subscribers to the Annales de l'Institut Pasteur": op. cit., note 11 above, p. 63. Regarding
Calmette's training project at the Pasteur Institute, see his correspondence: APIP, Saint-Pierre-etMiquelon, 22 February, 16 April and 22 August 1890.

16 For a general review of the French colonial doctors, see Pierre Pluchon (ed.), Histoire des médecins et pharmaciens de marine et des colonies, Toulouse, Bibliothèque Historique Privat, 1985. For the particular case of Indochina, see Laurence Monnais-Rousselot, 'Médecine coloniale, pratiques de santé et sociétés en Indochine française (1860-1939). Une histoire de l'Indochine médicale', PhD thesis, University of Paris VII, 1997, pp. $371-606$. 


\section{Calmette, Project Instigator?}

Very soon after the Saigon Laboratory was founded, its history became part of the Pastorian legend, although it did not officially become a daughter institute until 1904. Act One of the legend has to do with a letter from Eugène Etienne, Under-Secretary for the Colonies, to Louis Pasteur in 1890. Etienne was a member of the government commission that established a general government in Indochina, and he was soon to found the "colonial party". ${ }^{17} \mathrm{He}$ was soliciting the co-operation of the Pasteur Institute in setting up a laboratory in Saigon for rabies vaccination and the preparation of a smallpox vaccine. Albert Calmette, who was already fairly well-known and had experience in the Far East, was taking a course at the Institute at the time. Act Two involves Pasteur asking him to accept this mission in December of 1890. Even the meeting between the two men, which was to determine Calmette's career, has become legendary. Pasteur is supposed to have suggested that Calmette go to Saigon: "Calmette, sailor that you are, would you be willing to go there and carry out this task? If you agree, I will suggest to M. Etienne that he ask you to organize and direct the laboratory in question. Think about it and give me your answer quickly."

Calmette is supposed to have replied: "I've thought about it and I accept; I'm at your disposal and can leave whenever you like."18

Ministerial correspondence addressed to the General Government in Indochina and decrees concerning the creation of the Saigon Laboratory in late 1890 are easy to locate, but official correspondence before this date, and in particular the letter from Etienne to Pasteur, has not been found. ${ }^{19}$ Therefore the best record we have of the preparatory phase of the project comes from Calmette's letters, especially those to Corre.

In June of 1890 Calmette concluded his assignment in Saint-Pierre-et-Miquelon and returned to France. In August his promotion was announced, not without his first making sure he had secured important political support. In fact, Albert Calmette enjoyed backing from his own family, in the person of his older brother, Gaston, who was at the time a distinguished member of nationalist and colonialist circles, and was later to become director of the newspaper Le Figaro. Gaston was in a good position to receive information about France's health development policy in the colonies, since, according to his younger brother, he had in the past done favours for Georges Treille, the doctor whom Etienne had put in charge of the Colonial Health Corps. ${ }^{20}$ Thus, thanks to his elder brother, Albert was able to arrange a meeting with Treille in July.

He wrote to Professor Corre immediately afterwards: "I returned from Paris the day before yesterday and I will waste no time sharing with you the results of my visit to the Ministry: splendid! as splendid as I could have wished." He explained: "M. Treille is

\footnotetext{
${ }^{17}$ Charles-Robert Ageron, France coloniale ou parti colonial?, Paris, Presses Universitaires de France, 1976.

${ }^{18}$ Calmette himself probably gave his support to this legend. See the posthumous eulogy by Pasteur Vallery-Radot, 'Albert Calmette', Revue des Deux Mondes, 15 January 1934.

${ }_{19}$ Archives d'Outre-Mer, Aix-en-Provence (AOM), Indochine, Amiraux, 2511: Under-Secretary of State for the Colonies to the General Governor in
}

Indochina, 27 December 1890, 'Création à Saïgon d'un institut de bactériologie'.

${ }^{20}$ Some years earlier, Gaston Calmette had recommended his brother to Pierre Savorgnan De Brazza, at that time Commissaire Général of the French Government in the Congo. Albert Calmette gave up the prospect of an "African career" because of his marriage. See Bernard, op. cit., note 11 above, p. 54 . 
reserving a special position in Saigon for me, to create a laboratory for the study of exotic bacterial and parasitic diseases." Further on he added: "In short, this is perfect! Treille seized upon my suggestions and accepted everything I asked for. I will do my utmost to produce something interesting over there; the substance is certainly not lacking! There is plenty of work to be done." 21

While this chronology of events runs counter to legend, it is at times in keeping with it, since Calmette's letters mention that, in addition to a delay for his future assignment (thanks to a temporary position at the newly-created Navy Medical School in Bordeaux, at his request), he obtained "leave with full pay, from October 1 to mid-December, to be spent at the Pasteur Institute”. Yet in all likelihood Calmette's first contact with the Pasteur Institute occurred only after steps had been taken within the Colonial Health Services. It was not until early September, in another letter to Corre, that Calmette wrote: "I sent a first letter to M. Roux, requesting that he include me in the first group of doctors to attend classes when they begin again in October."22

The official version once more agrees with reality. What Calmette's biographers have written about his brief stay at the Pasteur Institute correlates with this tardy contact. Calmette was not able to register in time to be admitted to the "Grand Cours" according to standard procedure. Nonetheless, "thanks to a well-deserved favour", and especially to his work on le rouge de morue he was given a "small private laboratory" where Dr Emile Roux visited him daily. ${ }^{23}$

Calmette did not however wait for Pasteur's offer, since by October 1890 , or by the time he arrived at the Institute, he had already begun to draw up an organizational plan for his future laboratory, in order to submit it to Treille. The rough draft is nearly identical to official documents approving the creation of a laboratory in Saigon and the mission entrusted to Dr Calmette. ${ }^{24}$

The first part of the project involved a commitment to "bacteriological research and the experimental study of infectious and parasitic diseases in warm climates ....". It fulfilled Calmette's most cherished hopes, but it also marked the beginning of a new colonial policy for France, driven by Etienne and with the aim of scientific expansion. One of the most original features of the project involved bringing together basic research and practical services which were expected to have an immediate impact. The task entrusted to the laboratory, of examining the possibilities for the local production of animal vaccines, reflects a health policy begun in Indochina by Navy doctors in the late 1860s; most European governments adopted similar practices in their respective colonies, with varied success. Calmette described the numerous technical, administrative, and financial setbacks suffered by smallpox vaccination campaigns in Indochina, and the poor results: the use of vaccine lymph imported from France or other Far Eastern countries required that it be maintained in "carrier" children, a method which was not always certain to work. Calmette added that the parents of these children "were paid an allowance by the administration [as were the vaccinating doctors]". Yet he also insisted on the key role the laboratory could play for neighbouring colonies:

21 APIP, Lamballe, 28 July 1890.

22 Ibid., 6 September 1890.

23 Bernard, op. cit., note 11 above, p. 45.
24 The rough draft was sent to Corre on 10 October 1890: APIP, Fonds Indochine. Concerning the official documents, see note 19 above. 


\section{The Beginning of Albert Calmette's Pastorian Career}

Of all the exotic colonies France owns, Cochin-China would be the first to have a regular animal vaccination service, where biological research could be carried out on the genesis of infectious diseases in warm climates and means of defence.

The laboratory's final role was to act as a rabies department, thus bearing the emblem of the Pasteur Institute, so that: "People who are bitten in China, Japan, and in the Dutch Indies can come here for treatment." 25

\section{Unclaimed Paternity}

The Pasteur Institute in Paris provided scientific collateral for Calmette's project and served as a model for it. Calmette himself was the first to describe the Saigon Laboratory as a miniature version of the Institute (l'Institut en petit); the expression was picked up by posterity. ${ }^{26}$ His role in drawing up the project was consequently diminished to that of a simple administrator, valued above all for knowing how to master quickly Pastorian techniques during an accelerated training period at the Institute.

There is no doubt that, regardless of the part played by each actor, the acceptance of the project was connected to a new, powerful alliance between the scientific institution and the colonial powers, both of whom enjoyed heightened power at the end of the nineteenth century. The official version, whereby the colonial authorities solicited the help of the Pasteur Institute directly, emphasizes the Institute's prestige and its vocation for public service. This vocation was already recognized in France and would thus be established in the colonies, in response both to public health needs, as was the case in Indochina, and to purely economic problems, as would later be the case in Tunisia. ${ }^{27}$

Once the mission had been entrusted to him, even in his personal correspondence, Calmette did not try to re-establish a more truthful version of events, except perhaps through ironic remarks about his hierarchical superior. During his journey to Saigon, Calmette wrote: "M. Treille will be delighted to see that this mission, which he now believes was his idea, has met with the success he hoped for."28

Is it possible that Calmette subsequently regarded his work in Saigon as less important than his later endeavours, to avoid-in the eyes of the Institute-emphasizing a more decisive role than that which legend alone confers upon him? Even though his later scientific accomplishments outshone his early research, he continued to praise the Institute's overseas work and civilizing mission, with "his" laboratory representing the first of its kind. From that point on his career was tied to the fate of the Pasteur Institute.

The phenomenon goes far beyond Calmette's personal agenda. The conditions in which the Pasteur Institute developed in France and the creation of a scientific community contributed to the development of a veritable "myth" surrounding Louis Pasteur, whose initial work was perceived as the revelation of a primary and universal truth; the research of scientists and doctors associated with his school was merely an extension of this truth.

25 APIP, ibid.

26 When Treille visited the Pasteur Institute, Calmette wished, by making this comparison, to praise the future Saigon Laboratory: APIP, letter to Corre, 17 October 1890.

${ }^{27}$ The second Overseas Pasteur Institute was created in Tunis at the request of French settlers in order to improve vinification. Regarding the Tunis Institute, see Kimberly A Pelis, 'Pasteur's imperial missionary: Charles Nicolle (1866-1936) and the Pasteur Institute of Tunis', PhD thesis, Johns Hopkins University, 1995.

${ }^{28}$ APIP, Strait of Malacca, 3 February 1891. 


\section{Annick Guénel}

As Gerald Geison writes, "Pasteur's collaborators and disciples had cast their own fate with Pasteur's posthumous reputation." 29 The prestigious identity conferred by belonging to a Pastorian community depended on deep attachment to its "founder": the quasireligious organization of the Institute, described by Anne Marie Moulin, transformed Pastorians overseas into veritable "apostles" and missionaries. Although during his lifetime Pasteur witnessed the creation of only the first three institutes outside France (Saigon, Tunis, and Nha Trang in central Vietnam), both the centre of "worship" and the starting point for these grand missions remained the mother house which immortalized him. ${ }^{30}$

A few Pastorians, and Charles Nicolle in Tunis in particular, tried to bypass this structure by shifting the "centre", represented by the Parisian Institute, towards their own sphere of activity. ${ }^{31}$ It would seem that Calmette's path did not diverge from the general practice. Is this because his stay in Saigon was relatively short? Or is it rather because when he set out for Indochina he already saw himself as a fervent disciple of the Institute?

\section{The "Well-Trodden Path of Exotic Pathologies"}

The approach proposed for the Saigon Laboratory was relatively new. Rather than dispatching scientific missions to study specific epidemiological issues in temporary laboratories, ${ }^{32}$ it established a permanent centre specializing in local bacterial flora. Calmette thought that the equipment he brought along and his recent training at the Pasteur Institute would be sufficient to accomplish an ambitious programme: "I will do research on cholera, beriberi, leprosy, and malaria, as far as my means will allow", he confided to Corre before his departure. ${ }^{33}$ Without any preconceived notion of the priorities to be defined, he briefly considered the possibility of doing field work: "Of course, once I arrive, I will arrange to be sent on missions to places where cholera or other interesting transmitted or contagious diseases have been reported." 34

In reality, during his entire stay in Saigon, Calmette worked essentially as a laboratory scientist and bacteriologist. The Saigon hospital system provided more than enough material for study. In fact, Saigon was the best equipped city in Indochina, particularly with the military hospital, which was to be renamed Grall, where the laboratory was first set up. It also had the Cho-Quan Hospital created at the initiative of the Bishop of Saigon, which was the first hospital for natives of the city (both hospitals were built in 1861). The diseases observed in the two hospitals were not identical. According to the registers and terminology used at the time, most hospitalizations in the first were for dysentery, chronic diarrhoea, and fevers. Destitution and extreme poverty led the native population to turn to

\footnotetext{
${ }^{29}$ Gerald L Geison, The private science of Louis Pasteur, Princeton University Press, 1995, p. 273. On the "Pasteur myth", see also, Anne Marie Moulin, 'Patriarchal science: the network of the overseas Pasteur Institutes', in P Petitjean, C Jami and A M Moulin (eds), Science and empires: historical studies about scientific development and European expansion, Dordrecht, Klüwer Academic Publishers, 1992, pp. 307-22, on pp. 310-1.

${ }^{30}$ Anne Marie Moulin, 'Les instituts Pasteur de la Méditerranée arabe. Une religion scientifique en
}

pays d'Islam', in E Longuenesse (ed.), Santé, médecine et société dans le monde arabe, Paris, L'Harmattan, 1995, pp. 130-64, on pp. 135-6.

${ }^{31}$ Pelis, op. cit., note 27 above, p. 123-51.

${ }^{32}$ For a comparison with the strategies of laboratory development in British India, see Mark Harrison, Public health in British India: AngloIndian preventive medicine 1859-1914, Cambridge University Press, 1994, pp. 112-13, 150-2.

33 APIP, Paris, 17 December 1890

${ }^{34}$ Ibid., 28 July 1890. 


\section{The Beginning of Albert Calmette's Pastorian Career}

Western medicine, which had hardly touched Indochinese life. The diseases reported in the second hospital were more varied, although not as well-inventoried. Many patients presented what seems to have been a wide variety of skin disorders; but epidemics, smallpox, and cholera brought only a very small portion of the population to the hospital. ${ }^{35}$

\section{Experiments on Humans: Leprosy and "Koch's Serum"}

The hospital-laboratory duo offered another advantage, in addition to providing what was probably, after all, an almost complete sampling of local pathologies: it made experimentation possible. Before devoting himself almost exclusively to animal experimentation-during the time it took to set up the laboratory-Calmette began a therapeutic trial on patients with leprosy, one of the diseases he had planned to study. In fact, in 1890 the Pasteur Institute was keenly interested in the "cure" Calmette wanted to test. This interest was due in particular to its inventor, as the substance in question was tuberculin, or Koch's lymph, glycerin extract from cultures of the tubercle bacillus. However, this treatment was soon highly controversial. Not only did Koch's "miracle cure" have few positive effects in preventing tuberculosis of the lungs, but the trials turned out to be a disaster. The product was nonetheless tested for use against other diseases related to tuberculosis, such as tubercular lupus, with encouraging results. Calmette ordered a flask of "serum" from Berlin before leaving for Indochina, planning a trial on tuberculous leprosy, a form of leprosy characterized by nodules on the skin or mucous membranes. ${ }^{36}$ In March of 1891 (a month after his arrival in Saigon) he conducted the first trials on lepers. After the serum provoked "a severe feverish reaction with a dose of one milligram", in two of the five patients treated, and "an acute outbreak of lepromas on the thorax and face" in another, he pronounced what seemed a definitive verdict:

This lymph is decidedly a therapeutic fiasco, although it holds immense scientific interest, but I do not believe this is the way we will stop the formation of new tubercles after the elimination of the old necrotized foci. It seems to me that Koch's initial premiss is false. ${ }^{37}$

Despite his own disastrous trials, just two months later Calmette gave the tuberculin to the head doctor at the Cho-Quan Hospital. Was he prompted to do this by his interest in the phenomenon observed by Koch, later the basis of his own vaccine? The ensuing trial resulted in the death of a Chinese patient and put a stop in the colonies to this type of experimentation, which was already seriously questioned in Europe. In Calmette's later tuberculosis studies, no mention was made of these minor therapeutic leprosy trials.

When the trials were completed, the laboratory was ready for other kinds of work. Calmette had convinced the local administration to build a breeding centre for small laboratory animals in the zoological park in Saigon. He then announced his intention to pursue more in-depth studies of the leprosy bacillus. Did he really begin a few such studies and was he then quickly discouraged? Hansen's bacillus was hardly appropriate

35 AOM, Fonds Ministériels/ancien fonds, 324: “Cochinchine. Hôpitaux, 1861-63"; Amiraux 10542: "Hôpital Choquan, 1885". See also, Monnais-

Rousselot, op. cit., note 16 above, pp. 120-6.

36 APIP, Paris, 9 December 1890.

${ }^{37}$ APIP, Saigon, letter to Corre, 14 March 1891.
Calmette then took over Koch's experiments on guinea-pigs from bacillus cultures which, as he said, "grow very well". But we do not know more about what may be considered as his first work on the tuberculosis bacillus. 


\section{Annick Guénel}

for an experimental approach. Or did he simply decide, from the beginning, to turn his attention to other research? Calmette's tenacity seems above question, as his subsequent work shows, especially when his thoughts about his potential contribution to tropical bacteriology are considered. These can be found with the last mention of leprosy in his correspondence:

It will take a long time and I will need to sow a great deal in order to reap very little . . These bacteriological studies are so painstaking and so many scientists are delving into the same questions that it takes years of work to achieve results. Even the long lives of men such as Pasteur and the host of experienced men surrounding him are not enough. What I can do here will represent but a very small contribution to research already begun by several others; it is terribly difficult to do anything original today, as everywhere the path is well-trodden. ${ }^{38}$

\section{Discovering a Pathogenic Agent: Tropical Dysenteries}

By taking the "well-trodden path", beginning with dysentery in May of 1891, Calmette was also pursuing pathologies in which the colonists were particularly interested. Indeed, "dysentery" was considered "the great killer" in Indochina before malarial fever assumed that distinction during the conquest of Tonkin. ${ }^{39}$ Despite improved sanitary conditions for the troops, dysentery, which went by various names, continued to fill military hospitals and to send soldiers back home to France. ${ }^{40}$

The major medical literature of the nineteenth century, which is sprinkled with various postulates on infectious disease starting in the 1880 s, is very confusing when it comes to understanding dysenteric phenomena. ${ }^{41}$ There was still no microbiological proof of the existence of any pathological entity specific to the tropics, as a French colonial doctor named Dutroulau ${ }^{42}$ suspected. Consensus was reached at the turn of the century on a "unitary theory" (théorie uniciste) which, on the basis of anatomopathological data, associated the chronic diarrhoea endemic to warm climates with dysentery, which appeared to be the consequence of the first condition. ${ }^{43}$

Calmette had access to the autopsies of patients who had died of dysentery at the military hospital in Saigon (and at times to those at the Cho-Quan Hospital); this disease thus provided an ideal subject for practising microbiology. He summarized his research project and method in one of his articles on "endemic enterocolitis", which is the expression he preferred to "Cochin-China diarrhoea" or to "Cochin-China disease". He declared that he wanted to forget all that he had "read and learned about the nature of infectious dysentery": "The uncertainty of results achieved up to now by experimenters ... has made me resolve . . to study once again every bacterial species I encounter in the intestine and in which I recognize pathogenic properties which would affect animals."44

\footnotetext{
38 APIP, Saigon, 8 May 1891.

${ }^{39}$ Fernand-P Burot and Maximilien-A Legrand, Les troupes coloniales. Maladies du soldat aux pays chauds, Paris, J B Baillière, 1897, p. 52.

${ }^{40}$ See Philip D Curtin, Death by migration: Europe's encounter with the tropical world in the nineteenth century, Cambridge University Press, 1989 , pp. 13, 18, 30, 108.

41 Ibid., pp. 147-50.

42 Auguste-F Dutroulau, Traité des maladies des
}

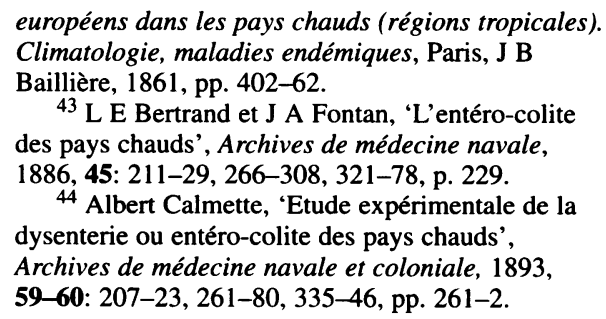
dysenterie ou entéro-colite des pays chauds', Archives de médecine navale et coloniale, 1893, 59-60: 207-23, 261-80, 335-46, pp. 261-2. 


\section{The Beginning of Albert Calmette's Pastorian Career}

For this detailed inventory of pathogenic species, samples of ulcers from dysenteric intestines would not be enough. In order to find bacteriological support for the unitary theory, Calmette also examined "stools from a large number of individuals with dysentery or fairly serious acute diarrhoea, or simply the bilious flow from the stomach which is so common in the Far East and which English doctors call sprue". 45

He planned to do "painstaking" experiments, "repeated several times", as he had been taught by his mentor Roux, to whom he decided "to write nothing, to send nothing . . . until I have significant, indisputable results". ${ }^{46}$ The methods he was using were classic: isolation of the pathogenic germ in humans, cultures and trials for transmission to animals, and, when possible, trials to induce immunity against the same germ. Two months after he had begun his research, he seemed to be onto what he called "curious" results. He proposed a candidate germ: "I currently have some rabbits to whom I have given generous immunity against infection from the microbe I'm studying, but I would like to induce immunity after infection. Herein lies the true difficulty."47 A short while later he confessed: "I still cannot reproduce this disease on a regular basis in experiments on animals. I have not found any that contract the disease the way humans do."48

Following brief presentations at the Academy of Medicine and the Biology Society, by 1892 he had nevertheless published in the main French tropical medicine journal at the time his first "note" on dysentery and the role of the Bacillus pyocyaneus. 49 (Had his experience with the rouge de morue inspired him to publish promptly?) He once again began taking samples from dysentery patients' intestinal ulcers and stools. He came to the conclusion that the bacillus was the only pathogenic bacterial species isolated which, when inoculated peritoneally in several different animal species, caused lesions that "present all the characteristics of true dysenteric lesions". 50

Meanwhile he was also doing more experiments on liver abscesses, recognized as often being associated with dysenteric phenomena. He shared news of some of the progress he was making with his colleague Alexandre Kermogant, who strongly encouraged him in this line of research. Yet, like Kartulis, Laveran and Netter, ${ }^{51}$ he had to admit that "generally speaking, the sterility of pus in liver abscesses was very likely", and mentioned the possible role of a toxin. ${ }^{52}$ Since he was unable to isolate a more specific germ, Calmette thought that the Bacillus pyocyaneus might be involved in "secondary infection" in tissue where other, more commonplace pathogenic species had paved the way. Calmette decided the Bacillus pyocyaneus played a decisive role in the fatality of the disease.

With hindsight, it appears very likely that at least some of the cases Calmette examined correspond to what we know today about amoebiasis. Yet the elimination of microorganisms present in the stools of healthy individuals, which Calmette records in great detail for both European and Asian subjects, did not allow him to conclude "that these

45 Ibid., p. 262.

46 APIP, Saigon, 22 May 1891.

47 Ibid., 4 July 1891.

48 Ibid., 30 January 1892.

49 Albert Calmette, 'Note sur la présence du bacille pyocyanique dans le sang et l'intestin de dysentériques en Cochinchine', Archives de médecine navale et coloniale, 1892, 57: 277-80.

${ }^{50}$ Calmette, op. cit., note 44 above, p. 277.

\footnotetext{
${ }^{51}$ Stephanos Kartulis, 'Einiges über die Pathogenese der Dysenterieamöben', Centralblatt für Bakteriologie und Parasitenkunde, 1891, 9: 365-72; Alphonse Laveran and Arnold Netter, 'Deux observations d'abcès du foie. Examen histologique et bactériologique du pus de ces abcès', Bulletins et mémoires de la Société des Hôpitaux de Paris, 1890, 7 (3ème sér.): 691-7.

52 Calmette, op. cit., note 44 above, p. 338.
} 


\section{Annick Guénel}

organisms [amoebas] are more abundant in patients with dysentery". He tended "rather to suppose that they were useful auxiliaries for macrophage cells in the intestine". 53 Nevertheless, he thought the amoebas studied a few years earlier by Kartulis ${ }^{54}$ were able to "produce the same disease with the same characteristics". ${ }^{55}$ As was true of the research of many of his contemporaries, Calmette's research, which was essentially directed towards reproducing dysenteric phenomena in animals, only skimmed the surface of actually discovering the existence of two amoebic cycles, one pathogenic and the other not.

In any event, for posterity and for the Saigon Laboratory, he accomplished bacteriological studies on drinking water in addition to this research. It was perhaps with future research on dysentery in mind that, as soon as he arrived in Saigon, he aspired "to be liked by the city authorities, or at least to attract their attention" by undertaking studies on the city's water, where the Bacillus pyocyaneus was found to be especially common. ${ }^{56}$ $\mathrm{He}$ also carried out analyses of water samples from certain administrative centres in Cochin-China that were of particular interest to Europeans, and adapted the Chamberland filter.

\section{Inventing a Vaccine: Cholera}

Apart from their practical, local implications, the results of his research on dysentery probably left Calmette feeling relatively dissatisfied. ${ }^{57}$ Although he was clearly dedicated and did not abandon this project until his return to France, after devoting several months almost exclusively to it, the project went through some stagnant periods (as the hospital did not always provide a sufficient number of dysentery cases). Therefore, in early 1892 , Calmette planned a second research project to examine local infectious pathologies. Cholera represented another way to take part in international competition.

Cholera, an endemic disease in Indochina, was the source of news that had the scientific world holding its breath. In 1892, after nearly two years of attempts, Haffkine succeeded in transmitting cholera to a guinea pig using an "intensified" (more virulent) bacillus, then he produced cultures of "attenuated" bacillus to prevent the disease in the same animal. The Pasteur Institute turned its attention to the Russian scientist's work, especially after a visit from the King of Siam and his interest in a method to prevent "Asian cholera". 58 Meanwhile, the Pasteur Institute and other European laboratories were beginning to concentrate on choleric poisoning, and Calmette received requests from them for fresh cultures of the bacillus from cholera patients in the various Saigon hospitals. It appeared he would have a golden opportunity to contribute to the research underway.

Before reading Haffkine's results in the July 1892 issue of Comptes-rendus de la Société de Biologie, Calmette had already experimented with the culture of the bacillus and its transmission to animals, and, like Haffkine, had experienced some setbacks. In the

53 Ibid., p. 221.

${ }^{54}$ Kartulis, op. cit., note 51 above.

${ }^{55}$ Calmette, op. cit., note 44 above, p. 342.

56 APIP, Saigon, 28 February 1891.

${ }^{57}$ However, Calmette was candidate for a French scientific award ("prix Blache"), following his works

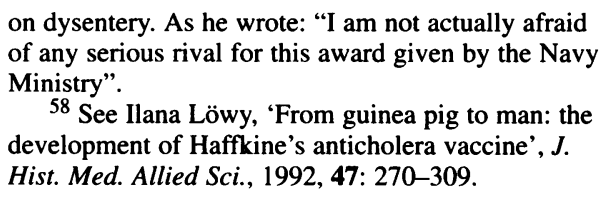




\section{The Beginning of Albert Calmette's Pastorian Career}

article on cholera that Calmette published in 1893 he nevertheless wrote that before this date he had managed to "intensify" the bacillus, or render it more virulent. He felt that it corresponded to "the toxicity growth of alternatively aerobic and anaerobic cultures"; in fact, infection in guinea pigs did not depend on the dose of bacillus ingested, but upon the toxins liberated in the cultures. ${ }^{59}$ The study of cholera toxins, which was therefore not entirely new, prompted Calmette to examine a means of developing "chemical immunity", the results of which were announced to Roux in October 1892. His method consisted of injecting guinea pigs with a glycerin extract of heated cultures of cholera bacillus, which Calmette called "virgulin", (in French, virguline, from bacille virgule) by way of analogy with Koch's tuberculin. A few limited animal trials showed that it had a preventive effect against subsequent ingestion of cholera culture and, so Calmette asserted, there were no side effects. ${ }^{60}$

Calmette's announcement of his results to Roux was accompanied by multiple precautions: he stressed that his research had to "remain in the purely experimental domain". Although even with those who were close to him he was very discreet about these experiments, which were "on the right track", he nevertheless hoped: "to attract a bit of attention from the scientific world, in spite of its being so absorbed with Haffkine's research and that of the Pasteur Institute on cholera vaccination". ${ }^{61}$

He was therefore somewhat anxious as he waited for Roux's reply and eventual criticisms, which were long in coming. By contrast, he was visibly pleased to hear the news Yersin sent from the Pasteur Institute about Haffkine's research. Calmette wrote:

It seems that as I feared, the poor boy spread the news about what he thought he had discovered far too quickly, and far too noisily. His findings are highly disputed today, and it's been pointed out to him, in the scientific sphere, that he merely reproduced what the Spanish doctor Ferran announced in 1886 . ... Yersin even told me that Roux was about to show him the door. ${ }^{62}$

Calmette himself had interests to defend at the Pasteur Institute and preferred to postpone publication of the cholera study, "for fear of offending M. Roux". ${ }^{63} \mathrm{He}$ was thus able to pursue "truly feverish research" right up to the eve of his departure:

What matters is making it to the finishing line in time, and there is a veritable steeple chase underway between European laboratories, especially Paris and Berlin. Although we all started from the same point (since they are using my cultures for their research), I chose to follow a different path. I do not want to vaccinate against cholera, as I am persuaded that it's utopian to try and vaccinate man against a disease that he can contract two or three times in a row, even at short intervals! I'm conducting an in-depth study of the toxin secreted by the microbe, and trying to neutralize it in the infected organism, or eliminate it. I already have important results concerning one of these two solutions. ${ }^{64}$

The second solution, which consisted of eliminating the toxin using a relatively complex dialysis method, or "peritoneal dialysis", was based on the properties of the cholera toxin. It was the solution Calmette recommended as the most active in treating

59 Albert Calmette, 'Recherches expérimentales sur le choléra asiatique indochinois et sur l'immunisation chimique des animaux contre cette maladie', Archives de médecine navale et coloniale, 1893, 59: 216-67, pp. 218-23.
${ }^{60}$ Ibid., pp. 262-5.

61 APIP, Saigon, 24 September 1892.

62 Ibid., 2 October 1892.

63 Ibid., 28 January 1893.

64 Ibid., letter to Corre, 2 May 1893. 


\section{Annick Guénel}

confirmed cases of cholera. As for his chemical immunization method, in the article he finally published in 1893 he once again affirmed that:

It is very likely that they [Haffkine's cholera vaccination and chemical immunization] would be equally effective for our species, but we cannot envision subjecting the population of an entire country or even a city to this treatment, against an epidemic which is not a confirmed threat, and which, even if it were truly murderous, would hardly affect more than twenty people. ${ }^{65}$

Calmette's reservations about the effectiveness of cholera prevention over time, given the risks involved, may explain why he abandoned this project when he returned to France. Or did he decide to bow out of the race when he saw that Haffkine was continuing his trials or, rather, because Roux had begun his own research on choleric poisoning ? $^{66}$ In 1893, as his return drew near, Calmette had already adapted his plans with an eye to pursuing a career at the Pasteur Institute in Paris. Although he placed great hope in his cholera study, other research begun in Saigon would give him the chance to occupy a key position. Oddly enough, considering his initial ambitions, it would not fall in the domain of "exotic" infectious pathologies.

\section{Indochinese Diseases Caused by Bites: "Crazy Dogs" and the Naja tripudians}

Calmette's most original research into human pathologies in Saigon involved taking the first steps towards inventing snakebite serotherapy. In 1893 he returned to France crowned with two other successes, neither of which was related to purely tropical diseases: the development of the local production of animal vaccines, and the setting up of a rabies department.

The first of the two missions defined before Calmette's departure from France was amply examined above and has been discussed in a previous article. ${ }^{67}$ Calmette's correspondence offers very few new elements on the technical details and the initial difficulties with local cattle in supplying Jenner's vaccine. At the most, his letters mention problems with Chinese suppliers, who were hesitant to "loan" their animals "claiming the skins would not be worth as much". By June of 1891 Calmette announced a 100 per cent success rate with his vaccine, and other colonies quickly requested tubes and technical advice. He personally saw to it that the department ran smoothly, and was reluctant to hand over production of the vaccine to his assistant, Dr Lépinay, until the end of his stay in Saigon. Calmette made it a scientific point of honour that the department was run properly and that impetus was given to the fight against smallpox in Indochina; he was also aware that this emphasis lent legitimacy to the Saigon Laboratory. The new Governor General of Indochina, Jean-Marie de Lanessan, also a former Navy doctor, was to pay a visit but postponed it several times. Calmette awaited the governor's arrival to disclose his

\footnotetext{
65 Calmette, op. cit., note 59, p. 266.

${ }^{66}$ See Ilana Löwy, 'Le vaccin anticholérique à l'Institut Pasteur (1890-1895): Haffkine, Metchnikoff, Roux', in A M Moulin (ed), L'aventure de la vaccination, Paris, Fayard, 1996, pp. 195-209, on p. 207.
}

\footnotetext{
${ }^{67}$ Annick Guénel, 'Lutte contre la variole en Indochine: variolisation contre vaccination?', Hist. Philos. Life Sci., 1995, 17: 55-79.
} 


\section{The Beginning of Albert Calmette's Pastorian Career}

results. As mentioned earlier, supplying the colony with vaccine was a key task for the laboratory. Yet we should also keep in mind that as it involved a pre-Pastorian method of prevention, initially it simply provided an excuse for setting up laboratories, in Saigon and other overseas Pasteur Institutes.

\section{The Rabies Department}

Setting up a rabies department was the Saigon Laboratory's second practical mission. Although the mission is clearly described in the clauses creating the laboratory, the colonial doctors and administrators of Cochin-China's financial services did not immediately come to unanimous agreement about it, as they had with the first mission. Rabies very rarely affected Europeans. How could such a department serve public health in the colony, and how could its operational costs be justified? Moreover, in 1890 there were, generally speaking, very few reports on the diseases which affected the indigenous population.

The administrators of neighbouring colonies (Indonesia, Malaysia, etc.) were ahead of the French colonial authorities, having already taken measures against stray dogs. Calmette may therefore have presumed that rabies, which was observed relatively often in neighbouring colonies, was more of a problem in Indochina than the handful of reported cases might have led him to believe. ${ }^{68} \mathrm{He}$ wanted to be sure of a ready clientele, and at each of his Asian stop-overs during the trip to Saigon he carried out a veritable advertising campaign for the future rabies department, sending notes to administrators and officials (the Pastorian cure knew no frontiers!). He also campaigned for the animal vaccination department.

It's good that all the Far Eastern press is lending a hand in launching this affair, since the more people who come for rabies inoculations, and the more I am asked for anthrax or other vaccines, the more important my position will be . . ${ }^{69}$

Once he had reached Saigon, he continued his campaign, sending notices to "all the administrators and residents up-country, and the consuls of all the ports in the Far East", and asking for reports of "crazy dogs", about which existing medical literature gave only rare examples. This investigation was, however, carried out in a climate of scepticismand at times harsh criticism-created by certain doctors and colonial administrators. ${ }^{70}$

Calmette also prepared the vaccine, in anticipation of his first "clients". The virus could not be cultivated in vitro, and, in order to avoid maintaining it by too frequent inoculations in rabbits, he adopted Roux's procedure for conserving rabid marrow in pure glycerin. The first bite victims were sent from neighbouring countries by their governments (the first two children to be treated came from Singapore). Yet he also quickly treated "Annamites" or colonists from Indochina and, when the cadaver of a "crazy dog" was given to him, he performed tests on it. He kept careful records of the number of people vaccinated,

\footnotetext{
${ }^{68}$ See "Documents relatifs à la rage humaine canine en Indochine", included in: Albert Calmette, 'Notes sur la rage en Indo-Chine et sur les vaccinations antirabiques pratiquées à Saïgon du 15 avril au ler août 1891', Annales de l'Institut Pasteur, 1891, B: $633-41$, pp. 639-41.
}

${ }^{69}$ APIP, Strait of Malacca, 3 February 1891.
70 AOM, Gouvernement Général, 23 882: "Institut bactériologique de Saïgon, organisation, rapports médicaux du Dr Calmette 1891-93”. 


\section{Annick Guénel}

continued treatment whenever necessary, in contrast to what was done in France, and took all the necessary precautions in case a bite victim arrived in an advanced stage of the disease. In a very official letter, he notified the governor of the province that he declined all responsibility if the treatment failed. By March of 1892 he had treated 40 bite victims; only one, a nurse from Hanoi who arrived too late, died. In September of the same year a total of 69 "clients" had come for treatment. Over the next two months he received a "flood of bite victims", bringing the number of cases treated to 79; he no longer had any doubts about the validity of this enterprise.

This episode in the life of the Saigon Laboratory during Calmette's time there retains its legendary quality even today. Calmette's determination to demonstrate the relationship between "crazy dogs" in Indochina and rabies allowed him to leave the lasting stamp of the Pasteur Institute on the colony, and today his work is all the more applauded in Vietnam because rabies remains a significant public health problem there.

\section{Snakebite Serotherapy}

Despite what the most ferocious attacks on Calmette asserted, rabies was certainly not "imported" into Indochina, but the treatment for it was. By contrast, snakebite serotherapy was invented from research done on Indochinese soil. Often, however, people forget that Calmette merely carried out preliminary studies in Saigon, and that the invention of the process benefited from various collaborations, above all new research developments in European laboratories, especially the Pasteur Institute in Paris. Nevertheless, snakebite serotherapy took on even greater importance as a Pastorian emblem because it symbolized the fight against a local scourge.

Accounts also make much of the event that prompted Calmette to study snake venom, portraying it as a catastrophic local epidemic. During the monsoon, a village near BacLieu in Cochin-China was invaded by cobras (of the Naja tripudians, or Cobra capel species), and several inhabitants were bitten and died. The local administrator had some captured snakes sent to the laboratory. ${ }^{71}$ Calmette seized upon this opportunity for both a physicochemical study of venom and a physiological study of poisoning, which were possible thanks to his laboratory equipment and menagerie of laboratory animals: "Never before has a study of venom been attempted in such favourable conditions as the ones I have created here."

This research provided the basis for developing a method to induce immunity against venom. He perfected some venom "neutralization" processes (using potassium permanganate and gold chloride) after inoculating various animals with venom. While still in Saigon, he pursued the model of immunity through vaccination by examining the protective effects of an inoculation of warmed venom or repeated administration of increasing doses of virulent venom. This study was not, however, entirely conclusive, as, even with his best attempts, the most Calmette was able to obtain was a "state of

${ }^{71}$ For more about Calmette's report of the event: APIP, Saigon, 7 November 1891. Afterwards, because of the publicity concerning Calmette's work on snake venom, there were also many other reports in colonial newspapers on the event or on related subjects. Thus, Le Cochinchinois published, one year

later, an article ascribed to a Vietnamese practitioner (1, 8, 22 and 29 November 1892), entitled

'Revelations by an Annamite snake charmer'. The aim of this publication was, of course, to emphasize the "quackery" of native treatments against snakebites. 
resistance", and not real immunity: "It's rather a sort of mithridatism, a tolerance to low doses of poison, comparable to the kind acquired by prolonged use of plant poisons such as opium, or mineral ones such as arsenic", he wrote in an article drafted in Saigon in $1892 .{ }^{72}$

This research was later continued at the Pasteur Institute in Paris, but while still in Saigon Calmette hoped it would have significant repercussions. At the time, a slightly different variety of the same species of snake was killing more than 20,000 victims a year in the British Indies. Indeed, Calmette knew that the British government was offering a prize for a treatment against snake poisoning, and he was interested in applying for it. ${ }^{73}$ If, in addition, he could prevent the effects of poisoning by other snake species, his work would gain prestige among the international scientific community.

On Roux's advice, Calmette therefore undertook a broader study comparing the properties and toxicity of the venoms from various dangerous snake species in Asia, Europe and Australia. He concluded that their physicochemical properties were similar, and that they differed only in their toxic effects. Yet it was not until he published an article in 1894 that he clearly mentioned the analogy between snake venom and certain bacterial toxins. ${ }^{74}$ In fact, in the time between his first snake-venom studies and that date, a new type of cure had been conceived, namely therapeutic sera. After the identification of diphtheria and tetanus toxins, evidence had been found of the presence of corresponding specific antitoxins in the sera of animals immunized through chemically modified toxins. Serotherapy thus consisted of using the curative powers of sera from immunized sheep or horses. ${ }^{75}$ Calmette was encouraged by Emile Roux, who took part in studies on diphtheria toxin and who had recently experimented with antidiphtheritic serum at the Hôpital des Enfants Malades in Paris, attempting to develop a snakebite serum on an analogous basis. He initially managed to make animals immune to a venom injection. ${ }^{76}$ The serum drawn from these animals then prevented any kind of venom from killing another animal.

Serotherapy also represented an important step in understanding the mechanisms involved in immunity. In addition to its practical implications for treating humans, Calmette's work in Saigon continued with a more theoretical study on the mechanisms of immunity at the distant the Pasteur Institute in Lille, of which Calmette was named director in $1901 .^{77}$

Following this research, which was not entirely "Saigonese", the snakebite serum was distributed through daughter institutes. Like most other sera, it was never produced locally; the exceptions to this being the plague and rinderpest sera destined to treat human and animal diseases specific to Indochina. It is worth noting that this phenomenon is

\footnotetext{
72 Albert Calmette, 'Etude expérimentale du venin de Naja tripudians ou cobra capel et exposé d'une méthode de neutralisation de ce venin dans l'organisme', Archives de médecine navale et coloniale, 1892, 57: 161-90, p. 188.

73 APIP, Saigon, 30 January 1892.

74 Albert Calmette, 'Contribution à l'étude du venin des serpents. Immunisation des animaux et traitement de l'envenimation', Annales de L'Institut Pasteur, 1894, 8: 275-91, p. 284.

${ }^{75}$ See Edgar Relyveld and Maurice Huet, 'Une histoire des anatoxines', in Moulin (ed.), op. cit.,
} 


\section{Annick Guénel}

typical of the daughter institutes, at least before independence. Not only was study material from overseas used for basic research that ultimately took place in France, but the overseas Pasteur Institutes did not share in the "industrialization" of strategic therapeutic processes.

\section{Pastorian Applications and the "Régies"78 of the Colonial Government}

The other "Pastorian studies" on rice and opium fermentation benefited local industry more directly. More precisely, they benefited colonial industry, since the alcohol and opium trade played an important role not only in private colonial interests, but also in Indochina's general budget. ${ }^{79}$

There is no doubt that Calmette was interested in political and economic life in the colony. He noted the presence of certain, apparently rather conspicuous figures such as the "extremely wealthy purchaser from the Tonkin plantation", whom he had met on the ship coming to Cochin-China. ${ }^{80}$ Very soon after his arrival he got in touch with the director of the Indochinese Customs and Excise Services. In 1891 the colonial economy did not earn the same amount of revenues from local alcohol as from opium. Profits from the sale of opium went directly to the Customs and Excise Administration, while profits from rice alcohol went to the Chinese. According to a contract with the colonial government, the Chinese held a monopoly on the production of rice alcohol until 1894, thanks to the "secret" of "Chinese yeast". Yet, as Calmette wrote to Corre, "the colony could make a substantial income by producing high quality alcohol from rice". 81

By March of 1891 Calmette was planning to use the laboratory equipment for the "scientific study" of two types of fermentation, but he was encouraged to give priority to research on opium fermenting agents, which would potentially bring more immediate profit to the colony's finances. The relatively long lapse of time it took (ten to twelve months) to prepare "a good chandoo" (obtained from raw opium after a series of complicated procedures, and ready to be smoked) represented a significant loss of income for the administration. The role of airborne microbes in the fermentation of opium was not unknown, but the selection and study of active agents remained to be done. Calmette isolated a single micro-organism, Aspergillus niger, from some "very old opium, considered to be the best in the Régie", and determined the best cultivation and sowing conditions. In October he obtained a completely fermented product in the laboratory in just one month, from a new "chandoo". 82 The inspector from the Régie had the product tested by three "experts" (Chinese, "Annamite", and French) and gave a very favourable report:

They unanimously agreed that it was excellent, far superior to the Régie's opium. It tips much better, moulds more easily, can be smoked continuously and never catches fire (apparently a very important feature). It has a very enjoyable taste and aroma ... .

\footnotetext{
${ }^{78}$ Régie: this was the state administration for levying excise duties and for overseeing state monopolies such as alcohol, tobacco, etc.

${ }^{79} \mathrm{See}$, in particular, Chantal Descours-Gatin, Quand l'opium finançait la colonisation en Indochine. L'élaboration de la régie générale de l'opium (1860-1914), Paris, L'Harmattan, 1992.

80 APIP, 9 December 1890. Calmette also
}

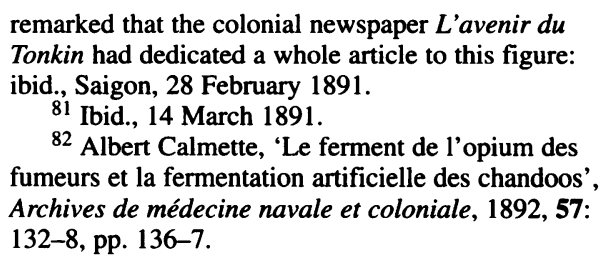

remarked that the colonial newspaper L'avenir $d u$ Tonkin had dedicated a whole article to this figure: ibid., Saigon, 28 February 1891.

${ }^{81}$ Ibid., 14 March 1891.

82 Albert Calmette, 'Le ferment de l'opium des fumeurs et la fermentation artificielle des chandoos', Archives de médecine navale et coloniale, 1892, 57: 132-8, pp. 136-7. 
The inspector even added that, according to the Chinese smoker, the experimental opium ranked favourably in comparison with the opiums that his very rich compatriots kept in a box from five to twenty years. ${ }^{83}$

Calmette's invention was quickly moved into industrial trials. In early 1892, “consumers could buy opium fermented for just 13 days!" Calmette also developed a test to identify contraband opium, which he and the Chief Customs Officer kept "absolutely secret". 84

The study of the fermentation of rice alcohol, which took longer than the opium study, concerned an "issue of immense fiscal interest for the colony". 85 It came at an opportune moment since in 1892 the Customs and Excise Administration planned to increase its income by adding rice alcohol to its tax regime. The Chinese used a very old, empiric process to manufacture the rice alcohol drunk in China and Indochina. It differed from Japanese saki, which was manufactured using partially studied fermenting agents. The Chinese yeast, produced from a complex plant preparation, possessed both the properties of saccharification and fermentation. It was much more active with rice than European processes for producing alcohol from grains, and offered the advantage of being produced locally. Calmette used this Chinese yeast, which was rich in bacteria and yeasts, to isolate the species that seemed to have the best saccharifying properties, which he named Amylomyces rouxii in honour of Emile Roux. ${ }^{86}$ Next he had to find a way to produce and cultivate this yeast, which develops abundantly on unhulled rice in the presence of beer wort. He combined it with another yeast from the Pasteur Institute in Paris, and eliminated certain pathogenic species present in the Chinese yeast. The outcome was excellent, and the yield was greater than that obtained by the Chinese. As he had discovered the secret of Chinese yeast, he could produce alcohol for Asian consumption and for exportation by altering the flavour with certain ingredients in the original recipe.

Calmette's letters, both personal and professional, reveal how important it was for him personally that his invention be used industrially. ${ }^{87}$ When he uncovered the secret of the Chinese manufacturers' yeast, he received offers for industrial production even before the end of 1892. Back in France, Calmette kept up with the administrative and commercial development of this business. ${ }^{88}$ The consequences of reorganizing and extending the Régie system under Paul Doumer (1897-1902) were no doubt profitable for the colonial budget, with the large opium, alcohol and salt divisions, but they were of questionable value to the local population. Justin Godard, who was appointed by the Popular Front government in France to study social issues in Indochina, recorded in 1937 the evil effects of opium and the more indirect ones of alcohol. He received complaints from certain

\footnotetext{
${ }^{83}$ Ibid., p. 137. See also the letter from the Régie surveyor, named Martin, dated 11 October 1891, added to Calmette's correspondance in the APIP.

${ }^{84}$ APIP, Saigon, 2 January 1892.

85 Ibid., 12 September 1891.

${ }^{86}$ Albert Calmette, 'Contribution à l'étude des ferments de l'amidon. La levure chinoise', Annales de l'Institut Pasteur, 1892, 6: 604-20, pp. 611-12, 619.

${ }^{87}$ On this subject, Calmette also sent letters to the Lieutenant Governor of Cochin-China, to the General Government of Indochina and even to the
}

Under-Secretary of State for the Colonies in 1892: AOM, Gouvernement Général, 23881.

88 The first candidate (named Blanchet) was the Messageries fluviales director. Calmette hoped to take part in any financial gain: APIP, Saigon, 2 July 1892. But another industrial man, Fontaine, played a more important part in this business. In 1899, he arranged an agreement with Calmette in order to use the patent and to ask for the alcohol monopoly in Annam: AOM, Gouvernement Général, 8908 and 4178 . 


\section{Annick Guénel}

villages where the population was required by the administration to buy a given quantity of alcohol, even though this was more than the inhabitants actually drank, thereby putting them even deeper into debt. ${ }^{89}$

Even so, at the end of the nineteenth century colonization was hardly being put on trial. Calmette's work on Chinese yeast, published in his first article in the Annales de l'Institut Pasteur, led to his candidacy to the French Academy of Sciences and was for many years cited as an important contribution to colonial works. By contrast, his studies on opium fermentation appear much more rarely in official discourses, articles, etc., about the Institute in Saigon, probably due to increasing pressure from international health commissions between the two world wars and to efforts to regulate the use of opium. Today this work has almost completely disappeared from the homage paid to Calmette for his role in creating the Saigon Institute.

At the time could he possibly have thought that his invention might cast a shadow over his other works in progress? In any event, he declared that he was "annoyed by $\mathbf{M}$. Treille's gossip about my fermentation of opium, as making a stir like this in the political newspapers is highly damaging". 90

\section{Calmette and the Colonial Environment}

Calmette's stay in Saigon was not his first encounter with a French colony nor with the Far East, but because of his new position he became more deeply involved in colonial circles. In the 1890s the European population in Indochina was still small, even if this southern city was already considered the "pearl of the Far East". 91 Very soon after his arrival Calmette commented: "the society is highly mixed and one should be on one's guard". 92 He remained reserved and limited outside encounters to the "interests" of the laboratory.

Except for visits from other colonial doctors, the visits Calmette organized or went on were of the official variety. Unlike Yersin, who became director of the Nha Trang Institute and later of all the Indochinese Pasteur Institutes, he did not regret these contacts, which he considered indispensable to establishing the laboratory in the colony. He gladly made use of the local press to advertise the laboratory and did not hesitate to solicit a decree from the Lieutenant Governor of Cochin-China for the requisition of carrier animals for the vaccine, to have "the satisfaction" of "always achieving [his] ends" and obtaining the premises and equipment he wanted.

He also hoped that De Lanessan, the Governor General in office in the early 1890s, would show an interest in his work, grant him personal recognition, or, at least, appreciate the key role that his laboratory could play in the work of colonization. The French government had just entrusted De Lanessan, a scientist and former Navy doctor, with the task of re-establishing colonial order, which was threatened in Annam and Tonkin. He quickly proved to be a poor communicator-he lacked understanding, and showed a

\footnotetext{
89 Justin Godart, Rapport de mission en Indochine, ler janvier-14 mars 1937, Paris, L'Harmattan, 1994, pp. 133-49.

${ }^{90}$ APIP, Saigon, 5 January 1892.
} 
"complete disinterest for anything other than politics". ${ }^{93}$ Despite Calmette's dashed hopes of any sort of recognition from the Governor General, in particular for his role in the colonial economy, he fully supported the "pacification" policy put in place by De Lanessan. $^{94}$

"Everyone trusts this energetic, fundamentally honest little man. If he cannot put things back in shape, then nobody can," judged Calmette. He considered De Lanessan's "policy towards the natives ... . very skilful and decent". Regarding the anger of the "Cochin Chinese" who watched their budget being swallowed up by "this cavernous money pit called Tonkin", once again he defended De Lanessan, who decided to undertake "this colossal expense, which would be considered incredibly foolish if its raison d'être were not well-known". 95

Calmette did not hold all French officials in Indochina in such high esteem, and scoffed at them freely, as he did at the Lieutenant Governor. Calmette thought him corrupt, or simply incompetent, and was delighted to see him replaced by an administrator who had been working in Indochina for many years and "was thoroughly acquainted with the country and its inhabitants". ${ }^{96}$ Calmette himself sought to know only what he needed for practical reasons directly connected to his subjects of research (especially for opium and rice alcohol). The rare occasions he had to meet local mandarins during official ceremonies, or his even rarer outings to some local celebrations, were not sufficient for him to take any real interest in the country. Indeed, he had nothing but contempt for the various "exotic decorations" he was given at the end of his stay, just when he was expecting to be nominated for the cross of the Legion of Honour! ${ }^{97}$ He did take on two "intelligent Annamites" at the hospital: "They are precious assistants for me, with whom I do as I please," he wrote. ${ }^{98}$

Calmette's notions of colonial law and power hardly differed from those of most of his contemporaries. He thought that allowing Chinese producers to retain a monopoly on rice alcohol was an enormous mistake for "our national industry . . . in a colony which, after all, exists only for the economic expansion of France, and not of the Chinese". 99 Along the same lines, in an account of Pastorian medicine's contribution to all the colonies, he later wrote: "Through the sacrifice of human lives, they [our respective armies] were able to impose our domination on the natives; but how could our trade have benefited if we had had to abandon the idea of settling there?" 100

\footnotetext{
93 Ibid., 13 February 1892.

94 For more about De Lanessan's colonial politics, see Charles Fourniau, Annam-Tonkin, 1885-1896. Lettrés et paysans vietnamiens face à la conquête coloniale, Paris, L'Harmattan, 1989, pp. 185-233. Regarding his scientific career: Damien Deschamps, 'Les sources scientifiques et la politique indochinoise de Jean-Louis de Lanessan', in ViêtNam. Sources et approches, Aix-en-Provence, Publications de l'Université de Provence, 1996, pp. 279-92.

${ }^{95}$ APIP, Saigon, 7 November 1891, 30 January and 24 September 1892.

96 Ibid., 26 August and 5 November 1892.

${ }^{97} \mathrm{He}$ wrote with some disdain that he had been
}

favoured with decorations from the Cambodian kingdom, from the Philippine consulate in Saigon, he had become an honorary member of an Egyptian Institute, and so on. But he was vexed not to have been honoured by the Dutch government, and did not wish to come into contact with the consul in Saigon who "is only a consular agent, of Prussian nationality and, at the same time, consul of Germany": ibid., 28 January 1893.

98 Ibid., 5 October 1891.

99 Calmette, op. cit., note 86 above, p. 607.

100 Idem, 'Le rôle des sciences médicales dans la colonisation', Revue scientifique, 1905, 3: 417-21, p. 417 . 


\section{Annick Guénel}

After spending three years in Saigon, Calmette remained "the man from overseas" in the Pastorian community until his death in 1933; his position as director of the Pasteur Institute in Lille, and as assistant director of the Institute in Paris, too often leads us to forget this detail. He was put in charge of organizing the Pasteur Institute in Algiers, and from 1910 to 1914 directed it from Paris (the brothers Etienne and Eugène Sergent were sent there as local delegates). He also founded the Institute in Athens in 1920, at the request of the Greek government, after creating a central office in Paris for the direction of the overseas Institutes. In 1925 Calmette drew up a contract with Noël Bernard, a new missionary of the Parisian Pasteur Institute in Indochina, to create an institute in Hanoi. They joined this third institute to the two existing ones, in Saigon and Nha Trang, creating a veritable federation.

From his vantage point in Paris or Lille Calmette watched over the future of the overseas Institutes, which he considered part of the "oeuvre of colonization, by making it eminently humanitarian and civilizing". He described the turning point taken by colonization in the $1890 \mathrm{~s}$, when the first laboratories, the precursors to the overseas Pasteur Institutes, were set up. This was the time when the fight against the major tropical epidemics changed the West's relationship with colonized countries. He also evoked the torch lit by the French institution, which served as an example to other major Western powers; in their turn they created bacteriological institutes in "nearly all the big tropical colonies . . . methodically explored by scientists whose discoveries had done a great service to colonization". ${ }^{101}$

\section{Conclusion}

Calmette endowed the laboratory with a solid base by developing practical services that were useful to public health and hygiene, and by carrying out research with industrial and commercial applications. In addition to producing and distributing vaccines and sera, and testing the drinking water in urban centres, the Saigon Institute provided applied chemistry services to local agrofood industries ${ }^{102}$ and medical analysis laboratories. This was to make it and the subsequent Indochinese institutes an indispensable part of the colonial health administration. ${ }^{103}$

In Saigon Calmette tried to put into practice the "Pastorian ideal" that closely linked basic research and applications. The work on the vaccine, which was produced using a local animal, the buffalo, could even appear as a "reinvention" of Jenner's vaccine and a genuine illustration of the ingeniousness of the Pastorian school. At the same time Calmette always sought to maintain a certain degree of dependence between research

101 Ibid., p. 418.

102 In 1914, Calmette, at the time director of Pasteur Institute in Lille, took the initiative to begin studies on "nuoc-mam" (an important traditional food product obtained by fish fermentation in Vietnam). A food control service was set up in the Pasteur Institute in Saigon, allowing the colonial administration to regulate the sale of nuoc-mam. See J Guillerm, L'industrie du nuoc-mam en Indochine, Saigon, Imprimerie A Portail, 1931, p. 7.

${ }^{103}$ It was ratified by the successive Pasteur
Institute's agreements with the General Government in Indochina. The 1925 agreement, negotiated by Noël Bernard, included a third Indochinese Institute, in Hanoi, and reinforced the "monopoly" of the Pasteur Institute in many health-related issues, such as biological and chemical analyses, vaccine production, and so on. For more about the agreements and the annual reports on the activities of Pasteur Institutes in Indochina, see: APIP, Fonds Indochine. 
carried out in Saigon and in France; his work on cholera illustrates this effort. And, although the overseas institutes would go on providing study material and data, and even serve as experimental grounds for testing new treatments, ${ }^{104}$ an imbalance between the development of practical services overseas and research activities was destined to continue.

While he successfully carried out the practical assignments entrusted to him and developed new applications, for a variety of reasons, Calmette had difficulty concluding studies of international importance in the Saigon Laboratory. For example, his venom study had to wait on new data from European science. The perplexity he initially showed, about "the well-trodden path" in microbiology may seem surprising in some ways; this was an era in which many of the multitude of pathogenic agents still had not been discovered. On the other hand, his attitude appears wise when one considers the increasingly apparent complexity of biological phenomena, and-above all-the fierce struggle between the major European powers to defend their scientific potential.

In his attempt to reproduce the Pastorian model of research, which he had idealized well before attending the Institute, Calmette suffered more from a lack of support from those he considered his new peers than from a lack of material means. Regardless of the reasons for his return to France, ${ }^{105}$ the explanation for the turn his career took in 1893 remains the same: he was too far from the Parisian centre, and science was done elsewhere than in the colonies. Upon his return to France Calmette did not immediately abandon all the projects related to his work in Indochina. However, snakebite serotherapy, the part of his research devoted to "exotic pathologies", which he continued to develop, was reoriented both towards understanding more general and basic mechanisms than those involved in poisoning, and towards more universal objectives than those applicable exclusively to the Indochinese colony.

As we have seen, Calmette was above all a laboratory scientist, as well as an administrator and unequalled strategist. These qualities were to be greatly developed during the course of his subsequent career. He was sufficiently occupied with his experiments to delegate to his colleagues in the military hospital, to whom he gave an occasional microbiology lecture, and the task of "gathering documents for the laboratory during their stays up-country". ${ }^{106}$ Not until a few months before his departure, in 1893, was he able to go in person to "continue a few small investigations in the field of indigenous pathologies" at the Cho-Quan Hospital. ${ }^{107}$ Calmette's most significant personal contribution to local epidemiological knowledge had to do with rabies; although this disease was probably more common in Indochina than in Europe, it was of relatively minor importance when measured against all the other local pathologies. Calmette's choices of study material were above all linked to the universal, dominant model of colonial public health in the nineteenth century, which was centred upon the "European

\footnotetext{
104 Such as the BCG vaccination. See Noël Bernard and Jean Bablet, 'Premiers essais en Cochinchine de la vaccination antituberculeuse des nourrissons par injection de bacilles B.C.G.', Bulletin de la Société Médico-chirurgicale de l'Indochine, 1925, 4: 192-6.

105 In his correspondence, he did not express the wish to stay in Saigon beyond the end of his regular
}

service time in Indochina and the appointment of a new laboratory director. His Pasteur Institute colleagues and biographers also said he was affected by chronic dysentery and asked to come back to France for this reason.

106 APIP, Saigon, 10 October 1891.

107 Ibid., letter to Corre, 17 February 1893. 


\section{Annick Guénel}

enclaves". ${ }^{108}$ The hospital, especially the military hospital, was his field of investigation. In this enclave to which he confined himself, it is hardly surprising that the main object of Calmette's concern remained the "microbe". He tracked and followed this microbe feverishly, and tried to confound its mysterious ruses in living organisms, but it was nonetheless relatively cut off from its human environment.

When he set up the laboratory, Calmette provided the instruments and determined the methods which would allow scientists to enrich their understanding of local epidemiology, but he did not launch any particular programme. He introduced the chief ambiguity of the Indochinese Pasteur Institutes (and the other colonial institutes) which, while safeguarding their scientific and administrative independence in relation to the colonial powers, modelled their programmes on colonial needs. In the case of a disease as major as malaria was in Indochina, far-reaching research with a methodical inventory of the local anopheline fauna was not carried out until 1925 . The malaria department created at this time, located at the Pasteur Institute of Saigon, responded to the needs of the colonial administrative and economic powers; they were faced with a public health problem created by the clearing and settlement of malaria-infected areas to make way for large-scale public works, especially in the north, or to build large plantations to cultivate the red earth in the south. ${ }^{109}$

Calmette was director of the Saigon Laboratory for a short time, but he laid sufficient foundations to establish the Pasteur Institute firmly in Indochina. His was a hard act to follow (for nearly twelve years after he left, most directors stayed no more than a year). The scientific events that mark the early history of the Pastorian presence in Indochina, such as Alexandre Yersin's discovery of the plague bacillus and Paul-Louis Simond's discovery of the flea's role in transmitting the plague, left the laboratory's progress in the shadows after Calmette. At the same time, they helped the institution to regain prestige. Even so, Yersin created his own institute in Central Vietnam and developed his plague serum there; Simond was himself director of the Saigon Laboratory only briefly, from 1898 to $1899 .^{110}$ These two discoveries did not in fact take place on Indochinese soil (but in Hong Kong and India, where the two Pasteur scientists had been sent on assignment); they testify more to Indochina's position as a platform from which the Pasteur Institute could send out missions than as a means of deliberate intervention in strictly local health problems. Later on, although Yersin became director of both the Saigon and Nha Trang laboratories in 1901, he differed from Calmette in that he adopted his host country for good and performed "local works", orienting his research more towards veterinary medicine and agronomy than human medicine.

One last question remains to be raised. What role did local factors play in the colonial appraisal of the Pasteur Institutes in Indochina? In particular, what was the influence of the creation of a native medical elite? Or, in line with David Arnold's question, did tropical medicine develop from a simple, passive transfer from France to the colony? ${ }^{111}$ It

\footnotetext{
108 See David Arnold, Colonizing the body: state medicine and epidemic disease in nineteenth-century India, London, University of California Press, 1993, pp. 61-115.

${ }^{109}$ L A Bordes, Le paludisme en Indochine (Historique, épidémiologie, état actuel de la lutte antipalustre), Hanoi, Imprimerie A Portail, 1931, pp. 15-17.
}

\footnotetext{
${ }^{110}$ Because of the Pasteur Institute's difficulties in finding directors among the Corps de Santé des Troupes Coloniales, Yersin had to take on the double directorship of the Saigon and Nha Trang Institutes in 1901 .

111 Arnold, op. cit., note 108 above, pp. 9-10.
} 


\section{The Beginning of Albert Calmette's Pastorian Career}

is, of course, inaccurate to speak of teaching the Indochinese the Pasteur Institute's theories and methods at the end of the nineteenth century. Although Calmette did recruit assistants locally, apparently he simply instilled in them the faithful reproduction of laboratory practices. By contrast, the medical school founded in Hanoi in 1902, of which Yersin was the first director, quickly added Pastorian theory and techniques to the curriculum for Indochinese medical assistants and doctors, most of them from Vietnam. Beginning in 1930, Vietnamese researchers co-signed medical articles with their French colleagues, especially in the Archives de l'Institut Pasteur d'Indochine, a journal created in 1925. Their skills were sufficiently recognized for them to be entrusted with positions of responsibility at the Pasteur Institutes, and at the head office of provincial health services. The determination to appropriate new knowledge, as much as the dearth of French doctors, meant that these native doctors were active participants in the development of public health and the progress made in understanding local pathologies. Their collaboration was welcomed by the Pasteur Institutes, and, with more disdain, by the colonial authorities, ${ }^{112}$ but the break caused by independence brought on the problem of the central role of the mother house. In 1956, following bitter negotiations, the Hanoi Institute, which Communist authorities wanted to be run by the Vietnamese without the need for approval from Paris, lost its title. As a result, the Indochinese federation that was so dear to the Parisian Pasteur Institute disintegrated. ${ }^{113}$ This was not, however, the end of the story that had begun with Albert Calmette. The commemoration of "his" Institute in 1991, in which the Institute in Paris took part, provided an opportunity to strengthen the old ties thanks to which the Parisian Institute continues to act as reference and which, even with Hanoi, had disappeared only temporarily.

112 See, in particular, Nguyên Van Huong, Hành trinh môt doi nguoi. Cuôc doi bac si Nguyên Van Huong, T.P. Hô-Chi-Minh, Nhà xuât ban van nghê, 1991, pp. 23-4.

\footnotetext{
113 Pierre Sureau and Michel Barme, 'Les dernières années de l'Institut Pasteur de Hanoi (1945-1956)', not published, 1992.
} 